Article

\title{
Impact of Climate Change: Environmental Assessment of Passive Solutions in a Single-Family Home in Southern Spain
}

\author{
Rafael Suárez ${ }^{1}$ (D), Rocío Escandón ${ }^{1 * *(\mathbb{D})}$, Ramón López-Pérez ${ }^{1}$ (D), \\ Ángel Luis León-Rodríguez ${ }^{1}{ }^{(1)}$, Tillmann Klein ${ }^{2}$ and Sacha Silvester ${ }^{3}$ \\ 1 Instituto Universitario de Arquitectura y Ciencias de la Construcción, Escuela Técnica Superior de \\ Arquitectura, Universidad de Sevilla, Av. Reina Mercedes 2, 410012 Seville, Spain; rsuarez@us.es (R.S.); \\ ramonlopezperez@gmail.com (R.L.-P.); leonr@us.es (Á.L.L-R.) \\ 2 Faculty of Architecture \& Built Environment, Delft University of Technology, Julianalaan 134, 2628 BL Delft, \\ The Netherlands; T.Klein@tudelft.nl \\ 3 Faculty of Industrial Design Engineering, Delft University of Technology, Landbergstraat 15, 2628 CE Delft, \\ The Netherlands; S.Silvester@tudelft.nl \\ * Correspondence: rescandon@us.es; Tel.: +34-954-559-517
}

Received: 20 July 2018; Accepted: 14 August 2018; Published: 16 August 2018

check for updates

\begin{abstract}
According to the IPCC Climate Change projections by 2050 temperatures in southern Spain will have increased noticeably during the summer. Housing —in its current form - will not be able to provide a suitable response to this new climate scenario, and will in turn prompt an increase in cooling energy consumption and a series of problems relating to health and comfort. The Design Builder simulation tool was used to quantify the impact of this future climate scenario on energy demand, as well as its effect under free-running conditions on indoor temperature. Different passive conditioning strategies were evaluated to establish their influence on the indoor comfort conditions. The case study examined a theoretical single-family residential unit model in order to establish guidelines for the pre-selection of the most suitable passive solutions. The results show that passive conditioning strategies analysed (envelope treatment, solar gain protection and night-time natural ventilation) reduce energy demand and indoor temperatures, thus increasing energy efficiency and improving indoor comfort conditions. Therefore, these passive conditioning strategies reduce the cooling energy consumption.
\end{abstract}

Keywords: climate change; energy efficiency; thermal comfort; passive conditioning strategies; night-time natural ventilation; Mediterranean climate

\section{Introduction}

Current environmental awareness faces a new challenge, that of the verified rise in temperatures on a global scale. Numerous researchers and associations have been warning of the risks of climate change. Since 1988 the Intergovernmental Panel on Climate Change (IPCC) [1] has collected this information in a series of reports compiling the most relevant research, together with the political and normative reactions aimed at mitigating the effects of climate change.

The latest IPCC report, Fifth Assessment Report (AR5) [2], includes the Physical Science Basis, gathering all the scientific data; the Impacts, Adaptation, and Vulnerability, which evaluate the consequences of the data collected within the Science Basis; the Mitigation of Climate Change, analysing potential ways to minimize or avoid the different impacts identified in the previous report; and the Synthesis Report, offering a summarized and simplified version of the entire Report. Additional special reports drawn up include the Special Report on Emissions Scenarios (SRES) [3], which shows a 
set of future scenarios classified according to social and economic variables and resulting in different evolutions of greenhouse gas emissions. Different hypotheses for greenhouse gas emission profiles based on socio-economic simulations lead to four scenarios with a particular climate forecast (A1, A2, $\mathrm{B} 1$ and $\mathrm{B} 2$ ). $\mathrm{A} 2$ is the scenario in which a higher $\mathrm{CO}_{2}$ concentration is predicted in the long term (year 2100), due to a fast population growth and a smaller increase in agricultural productivity. As stated in the H2020 requirements [4] and the subsequent legislation [5], energy efficiency is one of the ways in which climate change can be combatted.

The building sector in one of the largest energy consumer. A $25.4 \%$ of final end-use energy was attributed to the households category in the European Union 28 Member States (EU-28) in 2015 [6]. Fuller et al. [7] found that the location and the size are the dominant factors determining energy use in the residential sector. Du et al. [8] made use of empirical data at an individual and household scale to conclude that the building operational energy footprints are bigger in low-rise suburban households that in high-rise urban ones. In 2016, the population from EU-28 mostly did not live in flats, as a $23.9 \%$ lived in semi-detached houses and a $33.6 \%$ in detached houses [9].

Climate change will not only affect energy consumption [10] but also indoor comfort conditions [11], a crucial aspect given that the population is increasingly spending more time indoors (85-90\% on average) [12]. Tzikopoulos et al. [13] observed that in Mediterranean bioclimatic buildings energy efficiency decreased by $7 \%$ each 1500 degree hours, while building location also accounted for a variation of about $17 \%$. Yau and Pean [14] calculated that every temperature increase of $1{ }^{\circ} \mathrm{C}$ can reduce the coefficient of performance (COP) by $2 \%$. This increase in temperatures will therefore lead to a heightened risk of fuel poverty [15].

Although beneficial in heating periods, this temperature increase is particularly worrisome in refrigeration periods. Regions currently classified as warm, such as southern Spain, will suffer more extreme warm temperatures in a relatively short time scale, which could lead to a situation in which the current passive conditioning strategies are not sufficient anymore to provide comfortable indoor conditions. According to the projections of the IPCC, this new climate scenario will be similar to the one currently existing in North Africa and the Middle East.

By 2050 it will be necessary to incorporate renewable technologies for the passive cooling of buildings [16], together with predominantly passive cooling techniques, in order to reduce cooling and heating energy consumption in residential buildings [17]. Some researchers have proposed different passive strategies in warm and arid climates, similar to that expected in 2050 in southern Spain.

One of the first solutions proposed is the envelope improvement by controlling the energy exchange between the interior and exterior. A decrease in U-value through increased insulation results in a noticeable improvement in winter periods, although it can worsen environmental behaviour in summer. As regards thermal inflection, an increase in insulation thickness results in an increase in total demand, as studied by Idris \& Mae [18] in different climates and by León et al. [19] in the Mediterranean area. In the Mediterranean climate, energy consumption can be reduced with adequate windows and shading devices, as well as with roof insulation [20]. In the same way, thermal bridges lead to an increase in energy demand, not only in heating periods, but also in refrigeration as analysed by Al-Sanea et al. [21] in Saudi Arabia. If considering the building envelope as a dynamic energy store, thermal mass is used to manage the damping of the thermal wave during the day, with the subsequent heat dissipation during the coldest hours, while allowing for the stabilization of the indoor thermal conditions, as shown by some authors in hot and dry regions [22-24].

Roof ponds can provide year-round thermal comfort while reducing demand for active heating and cooling systems and increasing efficiency in hot and dry climates, as stated by Sharifi and Yamagata [25]. Roof ponds save energy through indirect evaporative cooling and radiant cooling and by mitigating the heat exchange between the roof and outdoor environment, leading to reductions in indoor air temperature up to $30 \%$ [26,27]. The different varieties and characteristics of roof ponds have been collected in Spanaki et al. [28]. 
The use of green roofs [29,30] reduces energy demand, increasing thermal resistance and decreasing solar gain according to the study by Goudarzi et al. [31] in Iran, which shows that this measure is more efficient than using a roof pond or an underground house. The energy efficiency of this measure can be enhanced by improving the thermal insulation, shading and thermal mass used in the design [32]. Ascione et al. [33] studied the impact of green roofs on heating and cooling energy saving and reported an expected energy saving of 8-11\% in Italy and Spain. Zinzi and Agnoli [34] compared the effect of cool roofs and green roofs on the energy performance of residential buildings. This study established that the use of green roofs leads to $2.8-13.9 \%$ cooling energy saving while for cool roofs this figure is in the range of $-13.7 \%$ to $30.1 \%$. Other authors [35,36] maintain that the use of cool roofs reduces the cooling needs with an average value close to $20 \%$.

The reduction of solar radiation through windows has been widely analysed based on multiple solar protection systems [37,38]. Double skin systems—-through ventilated claddings-are an adequate solution in climates with significant solar radiation. As different authors have studied [39] their thermal behaviour depends on different parameters: environmental conditions [40]; orientation; air chamber configuration [41] and ventilation conditions [42]; outer skin type [43] and base construction solution.

In order to be able to subtract heat from indoors, adequate mechanisms are needed for natural ventilation during the night, analysed and quantified by Solgi et al. [44], Santamouris and Kolokotsa [45]. This night-time ventilation should be combined with the heat accumulation processes in the thermal mass [23]. Campaniço et al. [46] studied and compared the cooling potential of four passive ventilation-based methods, including direct ventilation, Earth-Air Heat Exchanger (EAHE), controlled thermal phase-shifting and evaporative cooling, and reported that the use of above systems can provide up to $38 \%$ cooling demand saving. However, when outdoor conditions drop to the comfort levels during cooling periods, an increase in ventilation rates is beneficial [47].

In the future climate scenario characterized by rising temperatures, the challenged posed by buildings overheating must be addressed. The main aim of this work is the energy assessment (in free-running conditions, that is, no use of mechanical heating or cooling systems) of the main passive conditioning solutions applied to the single-family residential unit in southern Spain in the climate change scenario of 2050. In terms of indoor comfort following adaptive models, the analysis of the sensitivity and effectiveness of different passive conditioning solutions is proposed. This analysis is designed as a guide for the adequate pre-selection of different passive conditioning solutions, but a subsequent analysis should be carried out in order to find the optimal combined solutions.

\section{Methods}

In order to evaluate the impact that a climate change scenario would have on a single-family residential unit in southern Spain, this study uses a simulation model in compliance with the current demand stipulations of the Spanish CTE-DB-HE1 regulation [48]. Subsequently, the same model is used to evaluate the energy variables, but under the climate conditions predicted for the year 2050. Finally, some passive conditioning solutions are proposed to improve indoor comfort conditions under the 2050 climatic conditions.

\subsection{Characterization for Regulatory Compliance and Energy Assessment under Current Climate Conditions}

An initial theoretical model representing a single-family residential unit is proposed, with a thermal envelope defined by common construction solutions and in compliance with current regulatory requirements. Given the impact of orientation on the demand, the different strategies assessed take into consideration East-West as well as North-South orientations. DesignBuilder, Version 5.3.0.014 [49] software is used to simulate the energy evaluation, by means of the energy demand assessment and the indoor temperature in free-running conditions. The energy model recreates each room in the residential unit as a thermal zone. The average indoor temperature value weighted by the surface of each thermal zone is simulated for the free-running environmental analysis. 


\subsection{Energy Assessment under 2050 Climatic Conditions}

The influence of a climate change scenario on the energy behaviour of the single-family housing model is simulated. To do this, climate data are modified taking into consideration the climate change scenario forecast for the year 2050 and the previous energy model. In this projection the horizon is far enough ahead in the future to establish a certain prospect of change, yet close enough to avoid triggering the uncertainty of the results obtained.

CCWorldWeatherGen software developed by the University of Southampton is used [50] to convert the current climate data file from a specific location to another with future conditions using a climate change scenario [51]. Specifically, the case study used is A2 scenario, according to the IPCC Hadley Center Coupled Model Version 3 (HadCM3) [52], as it is the most unfavourable, according to the future prediction of $\mathrm{CO}_{2}$ particles per million.

After the subsequent simulation of the energy models with the DesignBuilder tool, the energy demand results are analysed and compared with the values obtained in current climatic conditions. Equally, the outdoor and indoor operative temperature evolution on a typical winter (30 January) and summer (24 July) day is analysed. This makes it possible to quantify the influence of the temperature increase in the 2050 scenario-in keeping with climate change projections-for a single-family residential unit conditioning in southern Spain.

\subsection{Environmental Assesment of Passive Conditioning Solutions for Improvement under the 2050 Climatic Conditions}

Once the impact of climate change on energy demand is assessed, different passive conditioning solutions to mitigate its energy impact are evaluated in a single-family residential unit. Temperature evolution is analysed in order to assess the environmental influence of these solutions applied to the simulation model in free-running conditions and compared with the adaptive comfort temperatures.

The comfort temperature bands from the optimum comfort temperature (Tco) are set up following adaptive standard EN 15251 (Equation (1)) during the winter period, with an acceptability range according to building category II, for a normal level of expectation (PPD $<10 \%$ ), that is, a temperature interval of $\pm 3{ }^{\circ} \mathrm{C}$. In summer, the adaptive comfort equation defined by Barbadilla-Martín et al. (Equation (2)) [53], for the specific case of hybrid or 'Mixed Mode' buildings (naturally ventilated through windows and with air conditioning equipment used intermittently) in the Mediterranean climate, is used. In this case, an acceptability range corresponding to $90 \%$ of satisfied occupants (PPD $<10 \%$ ) is applied, with a temperature interval of $\pm 3{ }^{\circ} \mathrm{C}$ In both cases, the running mean external temperature $\left(T_{e R}\right)$ is calculated according the Equation (3).

$$
\begin{gathered}
\mathrm{Tco}_{\text {winter }}=0.33 \times \mathrm{T}_{e R}+18.8 \\
\mathrm{Tco}_{\text {summer }}=0.24 \times \mathrm{T}_{e R}+19.3 \\
T_{e R}=(1-\alpha) \times T_{e d-1}+\alpha \times T_{e R-1}
\end{gathered}
$$

where: $T_{e d-1}$ : daily mean external temperature for previous day; $T_{e R-1}$ : running mean external temperature for the previous day; $\alpha$ : a constant between 0 and 1 . The use of 0.8 is recommended.

A widely accepted framework [45] to engineer passive cooling systems consists of three steps: the prevention of heat gains; the modulation of heat gains; and heat dissipation. Three types of strategies are therefore considered:

- Envelope treatment solutions

Thermal treatment of the envelope takes on two forms. Firstly, as a means to thermally separate the indoor environment from the outdoor one, that is, as thermal insulation. Façade Insulation (FI), Roof Insulation (RI) and Uninsulated Floor (UF) are proposed as solutions. The other form is the envelope's use as an energy pickup element and to soften temperature changes, which in turn increases 
thermal inertia. The solutions considered are Façade thermal Mass (FM) and Roof thermal Mass (RM). The use of Roof Ponds (RP), shallow pools of water built on the roof, incorporates a high volumetric heat capacity of water that allows the thermal mass of the roof to be increased.

\section{- Solar gain protection solutions}

At this point strategies aiming to avoid solar radiation on the constructive elements of the envelope would be included. These include Windows Solar Protection (SP), as well as double skin solutions such as Ventilated Façades (VF) and Ventilated Roofs (VR). The use of Green Roofs (GR) is also analysed, given that in addition to increasing thermal mass, they reduce solar gain thanks to the reflection and absorption provided by plants, as studied by Eumorfopoulou and Aravantinos [54]. In addition, a low absorptivity exterior paint-based finish is applied as a measure for the reduction of the solar Envelope Absorptivity (EA).

\section{- Ventilation solutions}

The entry of outdoor air can help ensure better indoor comfort conditions when this occurs following an adequate schedule, at night-time when the outdoor temperatures decrease. This will help to dissipate the accumulated heat during the day. Therefore, in the summer period, all strategies are evaluated with and without night-time natural ventilation. This allows the influence of ventilation on indoor comfort conditions and the effect produced by an increase in the night-time Natural Ventilation rate $(\mathrm{NV})$ to be evaluated.

\section{Case study}

The housing model selected for the development of the methodological process consisted of a living room, a kitchen, two bedrooms and a bathroom, with a surface of $58.30 \mathrm{~m}^{2}$ and a height of $3.00 \mathrm{~m}$ (Figure 1). The formal characteristics of this model are in keeping with those of a single-family residential unit typology, and it is considered versatile enough to allow conclusions to be reached that can be extended to a real case of architecture. This model is located in southern Spain, within a Mediterranean climate.

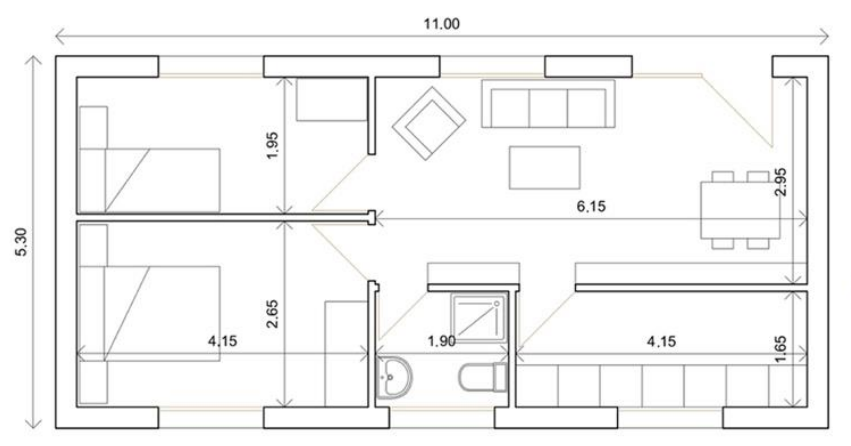

(A)

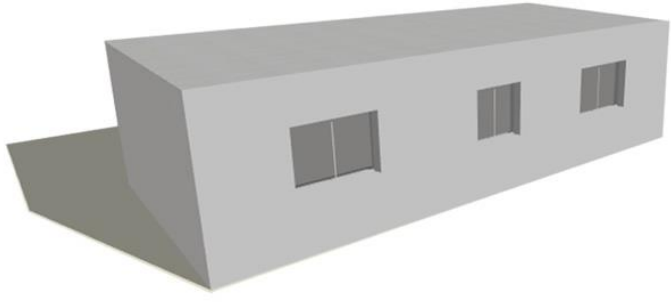

(B)

Figure 1. Residential unit. (A) Floor plan; (B) 3D model.

\subsection{Weather Data}

The case study is located in Córdoba, one of the Spanish cities with the highest outdoor temperatures during the summer. The Köppen-Geiger classification [55] places this city in the Csa climate, with a hot and dry period in summer, a maximum average temperature of $36.3^{\circ} \mathrm{C}$ in the warmest month and an absolute maximum temperature of $46.6^{\circ} \mathrm{C}$ in the month of July (Figure 2).

According to Spanish regulations CTE DB-HE1 [48], Córdoba is located in winter climate zone B, with a limitation of energy demand for heating of $15 \mathrm{kWh} / \mathrm{m}^{2}$ per year, and type 4 climate severity in summer, with a limitation of energy demand for cooling of $20 \mathrm{kWh} / \mathrm{m}^{2}$ per year. 
Córdoba (1971-2000)

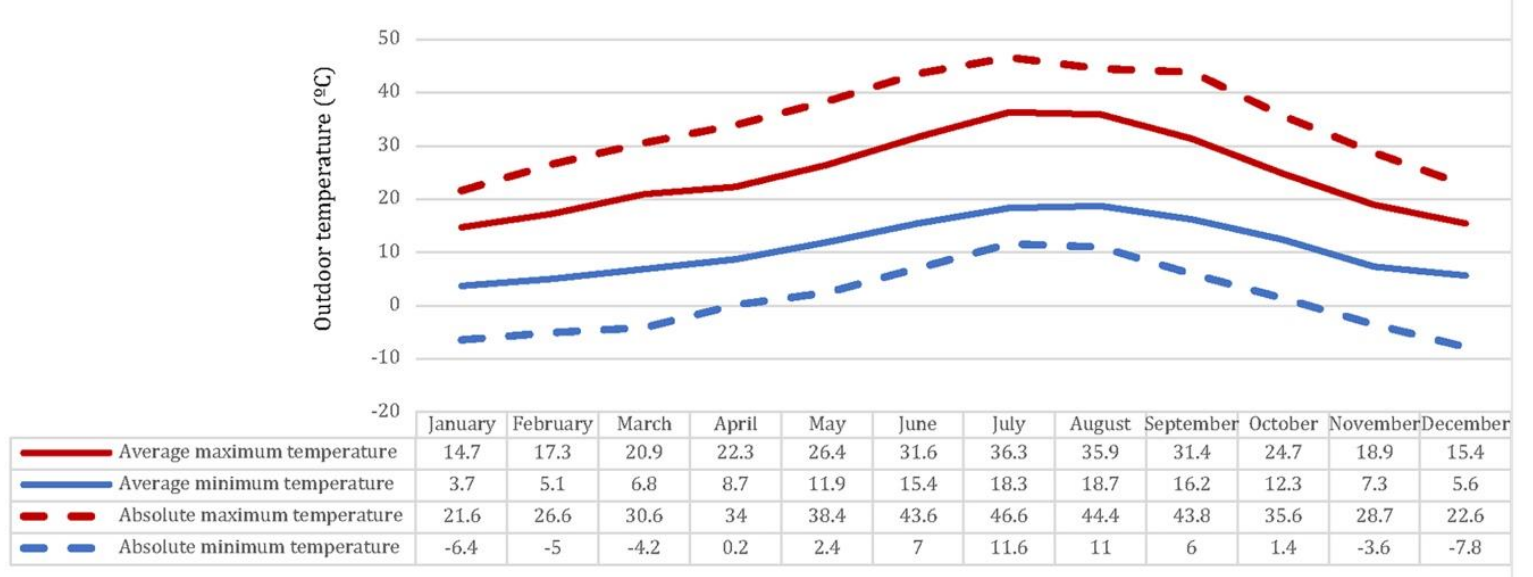

Figure 2. Case study climate values [56].

\subsection{Case Study Building Definition}

For the constructive characterization of the model, two types of layer are considered for the theoretical envelope, with one providing thermal mass and another providing insulation, greatly facilitating the subsequent analysis of passive solutions. The thermal mass allows the energy storage capacity of the envelope to be assessed, while thermal insulation mostly measures heat transmission capacity. Table 1 shows the envelope characterization, based on one of the most frequent construction typologies in southern Spain which is included in the CTE constructive solutions catalogue [57].

Table 1. Characterization of the thermal envelope of the base model (BM).

\begin{tabular}{|c|c|c|c|c|}
\hline Type & Layers (Outdoor $\rightarrow$ Indoor) & $\mathrm{U}\left(\mathrm{W} / \mathrm{m}^{2} \mathrm{~K}\right)$ & $\begin{array}{l}\text { Thermal Mass } \\
\left(\mathrm{kg} / \mathrm{m}^{2}\right)\end{array}$ & $\begin{array}{c}\text { Indoor Thermal } \\
\text { Capacity }{ }^{*}\left(\mathrm{~kJ} / \mathrm{m}^{2} \mathrm{~K}\right)\end{array}$ \\
\hline FB Façade & $\begin{array}{c}\text { Perforated brick }(1 / 2 \text { foot })+\text { No } \\
\text { ventilated air chamber }(5 \mathrm{~cm})+ \\
\text { Polyurethane insulation }(6 \mathrm{~cm})+ \\
\text { Double hollow brick }(7 \mathrm{~cm})\end{array}$ & 0.30 & 195.4 & 56 \\
\hline RB Roof & $\begin{array}{l}\text { Concrete }(20 \mathrm{~cm})+\text { Expanded } \\
\text { polystyrene insulation }(6 \mathrm{~cm})\end{array}$ & 0.47 & 490.0 & 0 \\
\hline FB Floor & $\begin{array}{l}\text { Expanded polystyrene insulation } \\
(5 \mathrm{~cm})+\text { Concrete }(15 \mathrm{~cm})\end{array}$ & 0.64 & 367.5 & 245 \\
\hline AB Window & $\begin{array}{l}\text { Metal frame (with thermal break), } \\
5 / 13 / 5 \text { double-glazing. Solar } \\
\text { transmission: } 0.82 \text {. Surface: } 10 \mathrm{~m}^{2}\end{array}$ & 2.68 & - & - \\
\hline
\end{tabular}

${ }^{*}$ The indoor thermal capacity is defined as the amount of heat required to change the temperature of the inner layer of the element. It is calculated by DesignBuilder software.

An infiltration rate of 0.2 Air Change per Hour $(\mathrm{ACH})$ and a natural ventilation rate of $0.4 \mathrm{ACH}$ are considered, in accordance with CTE DB-HS3 [58]. In addition, a summer night-time natural ventilation rate of $4 \mathrm{ACH}$ is considered from 23:00 to 9:00, in keeping with the official Spanish energy rating tool. The rest of parameters of the user profile (Table 2) are based on the data specified in CTE DB-HE [48]. In order to calculate demand, the set-point temperatures defined in Table 2 are applied, while the Heating, Ventilation, and Air Conditioning (HVAC) systems are completely deactivated for the free-running simulation of indoor temperatures. 
Table 2. Standardized user profile and occupancy pattern.

\begin{tabular}{|c|c|c|c|}
\hline Period & Presence & Set-Point Temperature & Natural Ventilation \\
\hline \multirow{2}{*}{ Winter } & Monday-Friday: 4 persons $24-8 \mathrm{~h}$; & $17^{\circ} \mathrm{C} 24-8 \mathrm{~h}$ & \multirow{2}{*}{$0.4 \mathrm{ACH} 24 \mathrm{~h}$} \\
\hline & Weekend: 4 persons $24 \mathrm{~h}$. & $20^{\circ} \mathrm{C} 8-24 \mathrm{~h}$ & \\
\hline \multirow{3}{*}{ Summer } & Monday-Friday: 4 persons $24-8$ h; & $27^{\circ} \mathrm{C} 24-8 \mathrm{~h}$ & \multirow{3}{*}{$\begin{array}{c}4 \text { ACH } 23-9 \mathrm{~h} \\
0.4 \text { ACH 9-23 h }\end{array}$} \\
\hline & 1 person $8-16 \mathrm{~h} ; 2$ persons $16-24 \mathrm{~h}$. & No HVAC 8-15 h & \\
\hline & Weekend: 4 persons $24 \mathrm{~h}$. & $25^{\circ} \mathrm{C} 15-24 \mathrm{~h}$ & \\
\hline
\end{tabular}

\subsection{Passive Conditioning Solutions}

As explained in Section 2.3, some passive conditioning solutions are evaluated, which mainly impact the insulation and thermal inertia of the envelope, the control of solar gains and the dissipation of accumulated heat. Energy models that simulate the behaviour of these solutions are used to assess their effect in terms of comfort. The simulation results are compared with the base model (BM), defined in the previous section for two orientations: North-South and East-West.

The following passive conditioning solutions are evaluated:

- Envelope treatment solutions

For the constructive characterization of this set of solutions, the decision was made to duplicate the thickness of the layer that provides thermal insulation or thermal mass to the constructive element. This allows the comparison of the effect of both strategies on indoor thermal comfort conditions.

Façade Insulation (FI): the thickness of the façade thermal insulation layer of the base model is doubled, increasing from 6 to $12 \mathrm{~cm}$.

Roof Insulation (RI): the thickness of the roof thermal insulation layer of the base model is doubled, increasing from 6 to $12 \mathrm{~cm}$.

$\bigcirc \quad$ Uninsulated Floor (UF): the ground floor thermal insulation layer is removed in order to evaluate its heat dissipating capacity.

- Façade thermal Mass (FM): the thickness of the layer that provides the main thermal mass to the base model façade is doubled, increasing from 12 to $24 \mathrm{~cm}$ of perforated brick.

- Roof thermal Mass (RM): the thickness of the layer that provides the main thermal mass to the base model roof is doubled, increasing from 20 to $40 \mathrm{~cm}$ of concrete.

$0 \quad$ Roof Pond (RP): a 30-cm-thick water pond has been included on the base model roof. As well as providing thermal mass, this solution favours the cooling process through evaporative loss, as the water temperature is $8-13^{\circ} \mathrm{C}$ lower than the air temperature [26].

- Solar gain protection solutions

The thermal transmittance of the base model constructive solution is maintained in this set of solutions, implementing those which exclusively affect the solar transmission of its envelope.

Solar Protection (SP): a solar screen is placed over the windows and it only allows the transmission of $5 \%$ of the solar energy to the indoors.

Ventilated Façades (VF): a ventilated façade solution, with a ceramic finish and chamber openings in its base and top, is incorporated into the base model.

V Ventilated Roofs (VR): a ventilated roof solution, with a ceramic finish and chamber opening in its perimeter, is incorporated into the base model.

- Green Roofs (GR): a plant layer is included on the roof of the base model. Stomatal resistance is set at $50 \mathrm{~s} / \mathrm{m}$; reflectivity of the plant leaves at 0.22 ; absorptivity at 0.6 ; and humidity percentage at $12.5 \%$ [54]. With these characteristics, the roof only allows the transmission of $18 \%$ of the solar energy to the indoors. 
Envelope absorptivity (EA): a new exterior finish is applied to the base model envelope (façades and roof), with a white reflective paint base, and with absorptivity values decreasing from 0.7 in the base model (BM) to 0.05 in the EA model.

- Ventilation solutions (NV)

In order to evaluate the influence of the night-time natural ventilation rate on the indoor thermal comfort level during the summer period, the ventilation rate established by the standard pattern is doubled from 4 to $8 \mathrm{ACH}$ following the schedule established in the Table 2.

Table 3 shows the main characteristics of the passive solutions which require a modification of the constructive configuration of the base model envelope.

Table 3. Characterization of passive conditioning strategies.

\begin{tabular}{|c|c|c|c|c|c|}
\hline \multicolumn{2}{|c|}{ Type of Strategy } & Layers (Outdoor $\rightarrow$ Indoor) & $\mathrm{U}\left(\mathrm{W} / \mathrm{m}^{2} \mathrm{~K}\right)$ & $\begin{array}{l}\text { Thermal Mass } \\
\left(\mathrm{kg} / \mathrm{m}^{2}\right)\end{array}$ & $\begin{array}{c}\text { Indoor Thermal } \\
\text { Capacity } *\left(\mathrm{~kJ} / \mathrm{m}^{2} \mathrm{~K}\right)\end{array}$ \\
\hline \multirow{6}{*}{$\begin{array}{l}\text { Envelope } \\
\text { treatment }\end{array}$} & FI Façade & $\begin{array}{l}\text { Polyurethane insulation }(12 \mathrm{~cm})+ \\
\text { Perforated brick }(1 / 2 \mathrm{foot})+\mathrm{No} \\
\text { ventilated air chamber }(5 \mathrm{~cm})+ \\
\text { Double hollow brick }(7 \mathrm{~cm})\end{array}$ & 0.18 & 198.4 & 55 \\
\hline & RI Roof & $\begin{array}{l}\text { Expanded polystyrene insulation } \\
(12 \mathrm{~cm})+\text { Concrete }(20 \mathrm{~cm})\end{array}$ & 0.25 & 490.0 & 215 \\
\hline & UF Floor & Concrete $(15 \mathrm{~cm})$ & 3.32 & 367.5 & 215 \\
\hline & FM Façade & $\begin{array}{l}\text { Polyurethane insulation }(6 \mathrm{~cm})+ \\
\text { Perforated brick }(1 \text { foot })+\mathrm{No} \\
\text { ventilated air chamber }(5 \mathrm{~cm})+ \\
\text { Double hollow brick }(7 \mathrm{~cm})\end{array}$ & 0.28 & 317.8 & 55 \\
\hline & RM Roof & $\begin{array}{l}\text { Expanded polystyrene insulation } \\
(6 \mathrm{~cm})+\text { Concrete }(40 \mathrm{~cm})\end{array}$ & 0.44 & 980.0 & 215 \\
\hline & RP Roof & $\begin{array}{l}\text { Water }(30 \mathrm{~cm})+\text { Expanded } \\
\text { polystyrene insulation }(6 \mathrm{~cm})+ \\
\text { Concrete }(20 \mathrm{~cm})\end{array}$ & 0.38 & 790.0 & 215 \\
\hline \multirow{3}{*}{$\begin{array}{l}\text { Solar gain } \\
\text { protection }\end{array}$} & VF Façade & $\begin{array}{l}\text { Ceramic tile }(2 \mathrm{~cm})+\text { Ventilated } \\
\text { air chamber }(5 \mathrm{~cm})+\text { Perforated } \\
\text { brick }(1 / 2 \text { foot })+\text { No ventilated } \\
\text { air chamber }(5 \mathrm{~cm})+ \\
\text { Polyurethane insulation }(6 \mathrm{~cm})+ \\
\text { Double hollow brick }(7 \mathrm{~cm})\end{array}$ & 0.30 & 195.4 & 55 \\
\hline & VR Roof & $\begin{array}{l}\text { Ceramic tile }(2 \mathrm{~cm})+\text { Ventilated } \\
\text { air chamber }(5 \mathrm{~cm})+\text { Concrete }(20 \\
\mathrm{cm})+ \text { Expanded polystyrene } \\
\text { insulation }(6 \mathrm{~cm})\end{array}$ & 0.47 & 490.0 & 0 \\
\hline & GR Roof & $\begin{array}{l}\text { Vegetation and sand }(10 \mathrm{~cm})+ \\
\text { Expanded polystyrene insulation } \\
(6 \mathrm{~cm})+\text { Concrete }(20 \mathrm{~cm})\end{array}$ & 0.40 & 560.0 & 215 \\
\hline
\end{tabular}

* The indoor thermal capacity is defined as the amount of heat required to change the temperature of the inner layer of the element. It is calculated by DesignBuilder software.

\section{Results and Discussion}

\subsection{Results in Current Climatic Conditions and the 2050 Climate Scenario}

The model simulation in the East-West orientation results in a higher energy demand than in the North-South orientation. Therefore, the case of the East-West model is considered to be the most unfavourable and the envelope parameters of the base model are adjusted to obey the regulation limits in this particular case. Demand in the North-South orientation is lower than that required by the current regulation (Figure 3). 


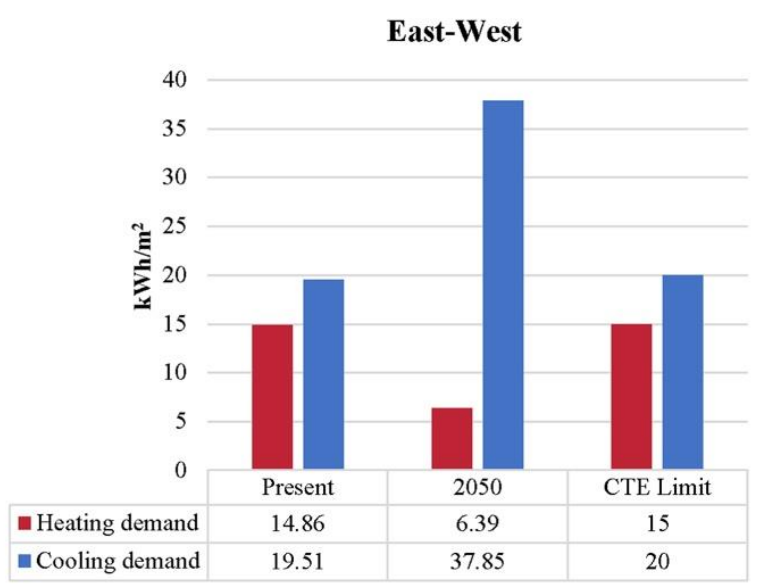

(A)

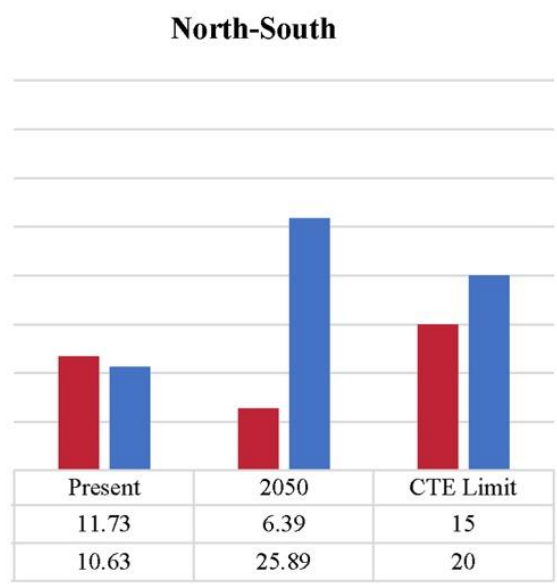

(B)

Figure 3. Energy demand for current and 2050 climate scenarios, compared to current regulatory requirements (CTE Limit). (A) East-West orientation. (B) North-South orientation.

A major impact is observed on energy demand after evaluating the energy behaviour of the base model in the 2050 climate scenario, without changing any of the parameters of the model. Heating demand is significantly reduced to a value of $6-7 \mathrm{kWh} / \mathrm{m}^{2}$, and is almost independent of orientation. In contrast, cooling demand is doubled in the North-South orientation with respect to the current conditions, and it reaches its highest value in the East-West orientation (Figure 3).

As Figure 4 shows, the new climate scenario results in an increase in outdoor temperatures. On the winter day represented there is an increase of $1-2{ }^{\circ} \mathrm{C}$, which becomes more significant in summer, with an increase of $6{ }^{\circ} \mathrm{C}$ during the day (reaching $47^{\circ} \mathrm{C}$ ) and of $4{ }^{\circ} \mathrm{C}$ during the night (with a minimum value of $24^{\circ} \mathrm{C}$ ). This outdoor temperature increase clearly affects the indoor operative temperatures. While in winter indoor operative temperatures barely increase by $1^{\circ} \mathrm{C}$, in summer climate change influence is much more noticeable, causing an increase of around $3-4{ }^{\circ} \mathrm{C}$, with the highest temperatures found in the East-West orientation.

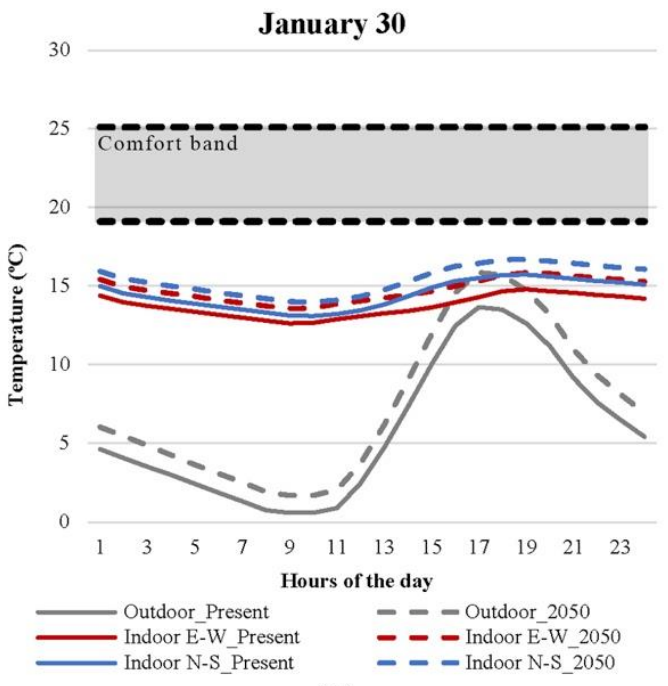

(A)

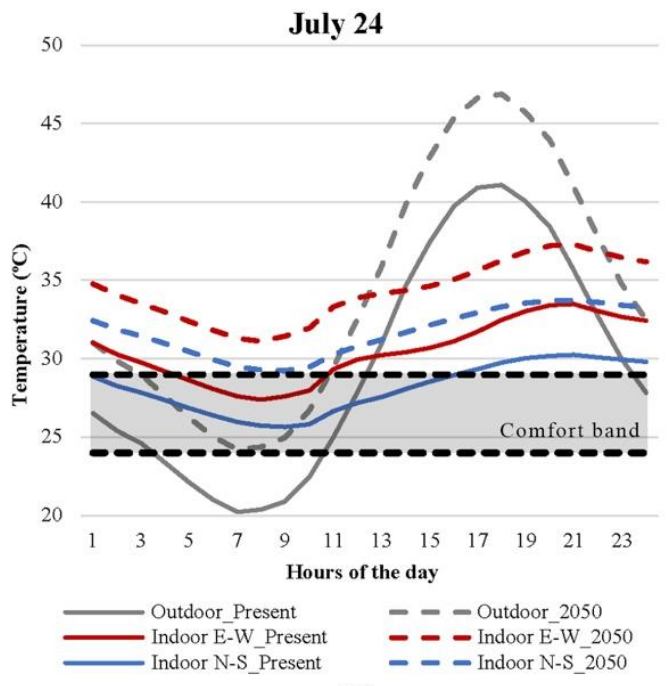

(B)

Figure 4. Evolution of the average indoor operative temperature and the outdoor air temperature in current and 2050 climate scenarios. (A) Winter. (B) Summer. 


\subsection{Energy Evaluation of Passive Conditioning Strategies in the 2050 Climate Scenario}

The major energy impact forecast for the future climate scenario makes it necessary to rethink the passive strategies currently applied in the thermal conditioning of single-family housing to improve thermal comfort in free-running conditions and to reduce energy consumption.

In winter (Figures 5 and 6), the solutions with the greatest effect on indoor conditions are the thermal insulation increase on the roof (RI) and the green roof (GR), which raise average indoor temperatures by up to $1.5^{\circ} \mathrm{C}$. Despite these improvements none of the individual strategies successfully increase indoor temperatures enough to ensure comfort conditions, and at best average indoor temperature is maintained at around $16{ }^{\circ} \mathrm{C}$. It should also be noted that some of the proposed solutions - the uninsulated ground floor (UF), the solar protection (SP) and the ventilated façade (VF)—involve a slight worsening of indoor conditions (average indoor temperature drops by less than $1{ }^{\circ} \mathrm{C}$ ). Solar protections could be deactivated during winter time, but not the other two strategies. In general, the indoor thermal conditions in the North-South orientation are slightly better than in the East-West orientation, although the differences in the average temperature do not exceed $1{ }^{\circ} \mathrm{C}$.

It is during the summer period in the 2050 scenario that the outdoor conditions are really extreme and the proposed solutions have a more significant effect (Figures 7 and 8 ). The positive effect of passive conditioning solutions is more evident in the East-West model, which displays worse thermal behaviour, than in the North-South one. The fact that the ground floor (UF) is not insulated provides a thermal dissipation that leads to a decrease in the average indoor operative temperature of up to $4.5^{\circ} \mathrm{C}$ (it goes from $34.5^{\circ} \mathrm{C}$ in the base model (BM) to $30^{\circ} \mathrm{C}$ in the UF model) and a drop in the maximum temperature from $37.5{ }^{\circ} \mathrm{C}(\mathrm{BM})$ to $32.5^{\circ} \mathrm{C}$ (UF), working out well for thermal comfort conditions during part of the day. The next most effective solution is the ventilated façade (VF), which results in a $1.5^{\circ} \mathrm{C}$ decrease in the average indoor temperature, maintaining the maximum temperature below $35.5^{\circ} \mathrm{C}$ compared to the $37.5^{\circ} \mathrm{C}$ of the base model (BM). The Roof Pond (RP) leads to a $1{ }^{\circ} \mathrm{C}$ reduction in the average temperature, as well as reducing the maximum temperature to $35^{\circ} \mathrm{C}$ thanks to the thermal mass increase. The increase in the night-time ventilation rate (NV) also causes the average temperature to fall by around $1^{\circ} \mathrm{C}$, significantly affecting the drop in minimum operative temperature at night-time, from $31.5^{\circ} \mathrm{C}(\mathrm{BM})$ to $29.5^{\circ} \mathrm{C}(\mathrm{NV})$.

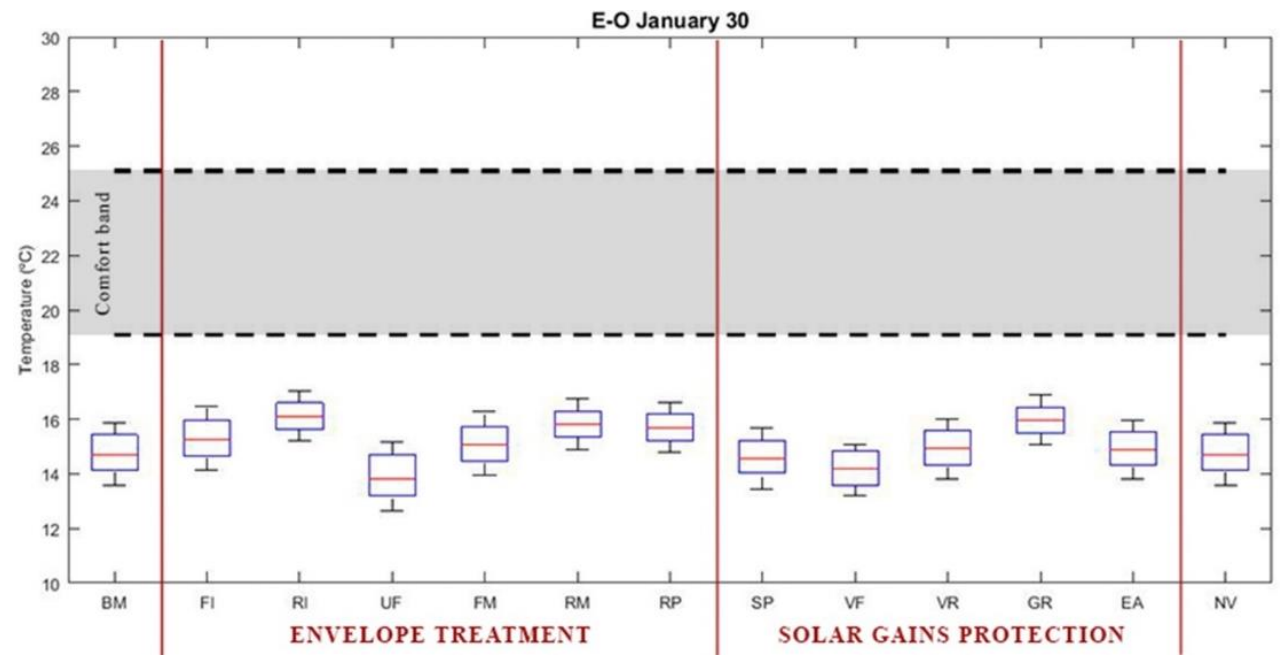

Figure 5. Daily fluctuation of the indoor operative temperature in the 2050 climate scenario with passive conditioning solutions. Winter, East-West orientation. LEGEND: Base Model (BM); Façade Insulation (FI); Roof Insulation (RI); Uninsulated Floor (UF); Façade thermal Mass (FM); Roof thermal Mass (RM); Roof Pond (RP); Solar Protection (SP); Ventilated Façades (VF); Ventilated Roofs (VR); Green Roofs (GR); Envelope absorptivity (EA); Natural Ventilation (NV). 


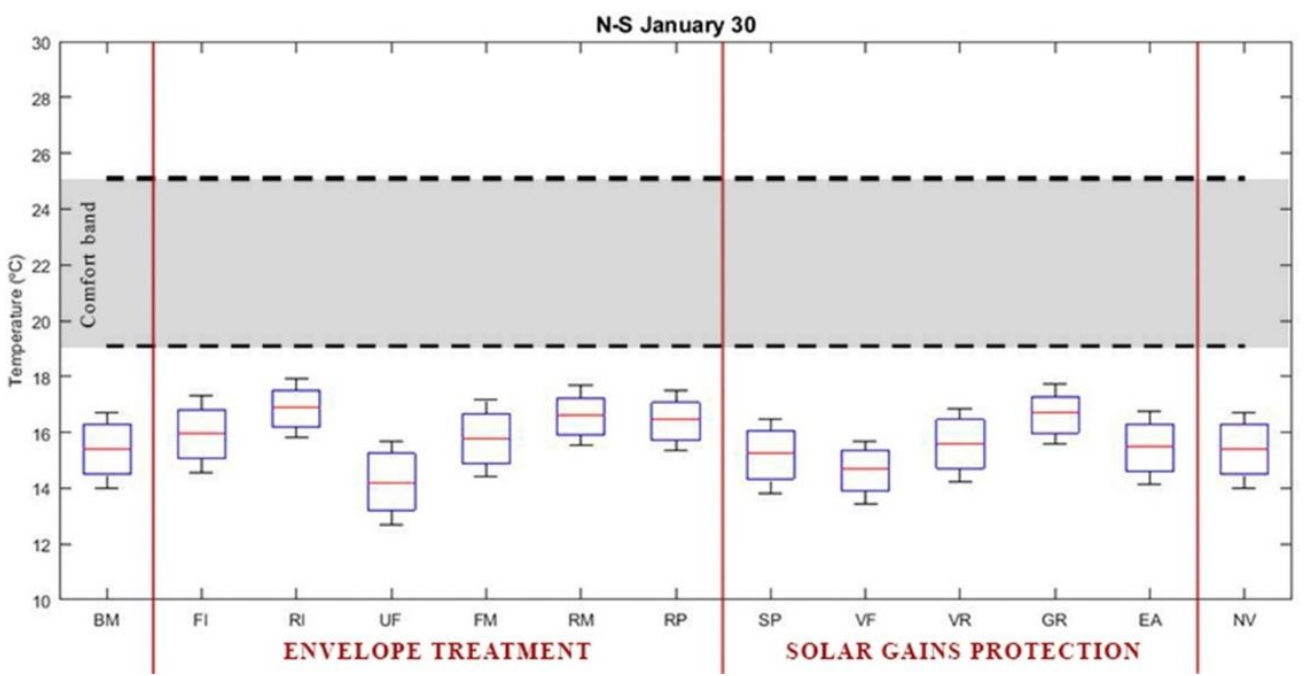

Figure 6. Daily fluctuation of the indoor operative temperature in the 2050 climate scenario with passive conditioning solutions. Winter, North-South orientation. LEGEND: Base Model (BM); Façade Insulation (FI); Roof Insulation (RI); Uninsulated Floor (UF); Façade thermal Mass (FM); Roof thermal Mass (RM); Roof Pond (RP); Solar Protection (SP); Ventilated Façades (VF); Ventilated Roofs (VR); Green Roofs (GR); Envelope absorptivity (EA); Natural Ventilation (NV).

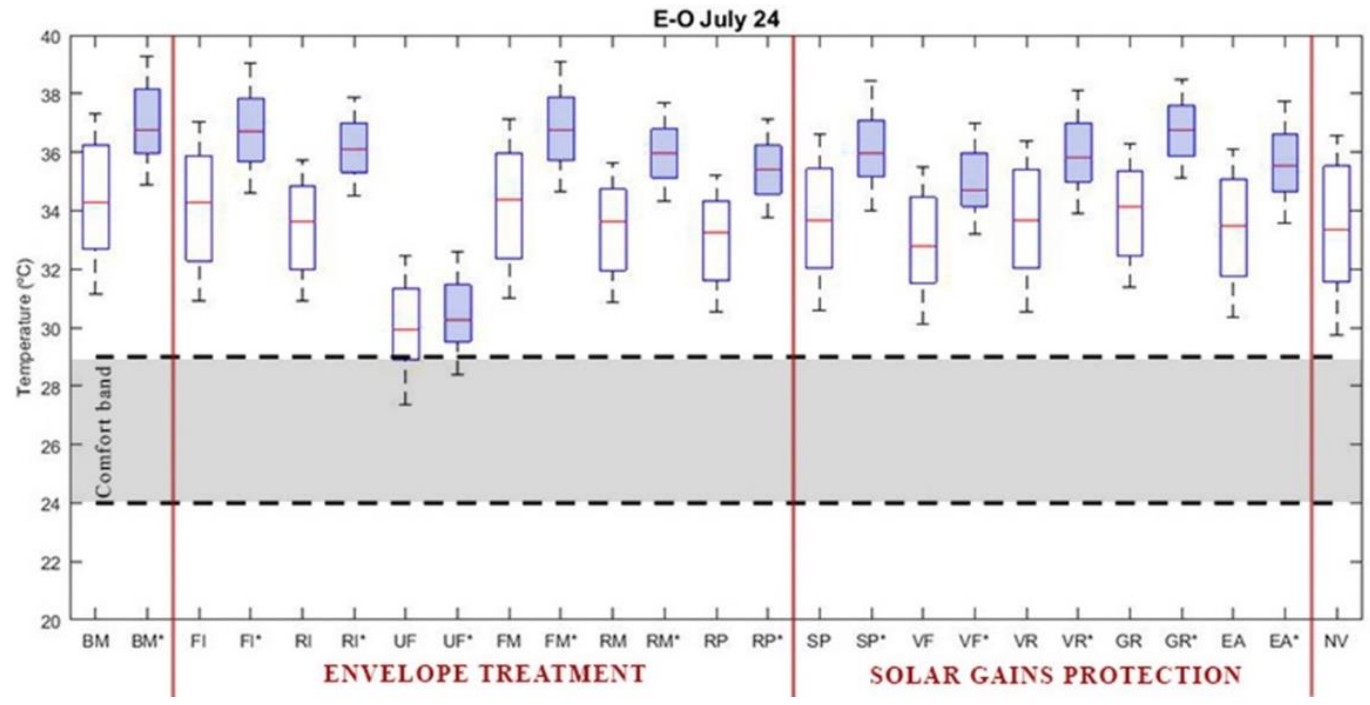

Figure 7. Daily fluctuation of the indoor operative temperature in the 2050 climate scenario with passive conditioning solutions. Summer, East-West orientation. NOTE: XX * (filled boxplot) is the XX passive conditioning solution but without night-time natural ventilation. LEGEND: Base Model (BM); Façade Insulation (FI); Roof Insulation (RI); Uninsulated Floor (UF); Façade thermal Mass (FM); Roof thermal Mass (RM); Roof Pond (RP); Solar Protection (SP); Ventilated Façades (VF); Ventilated Roofs (VR); Green Roofs (GR); Envelope absorptivity (EA); Natural Ventilation (NV). 


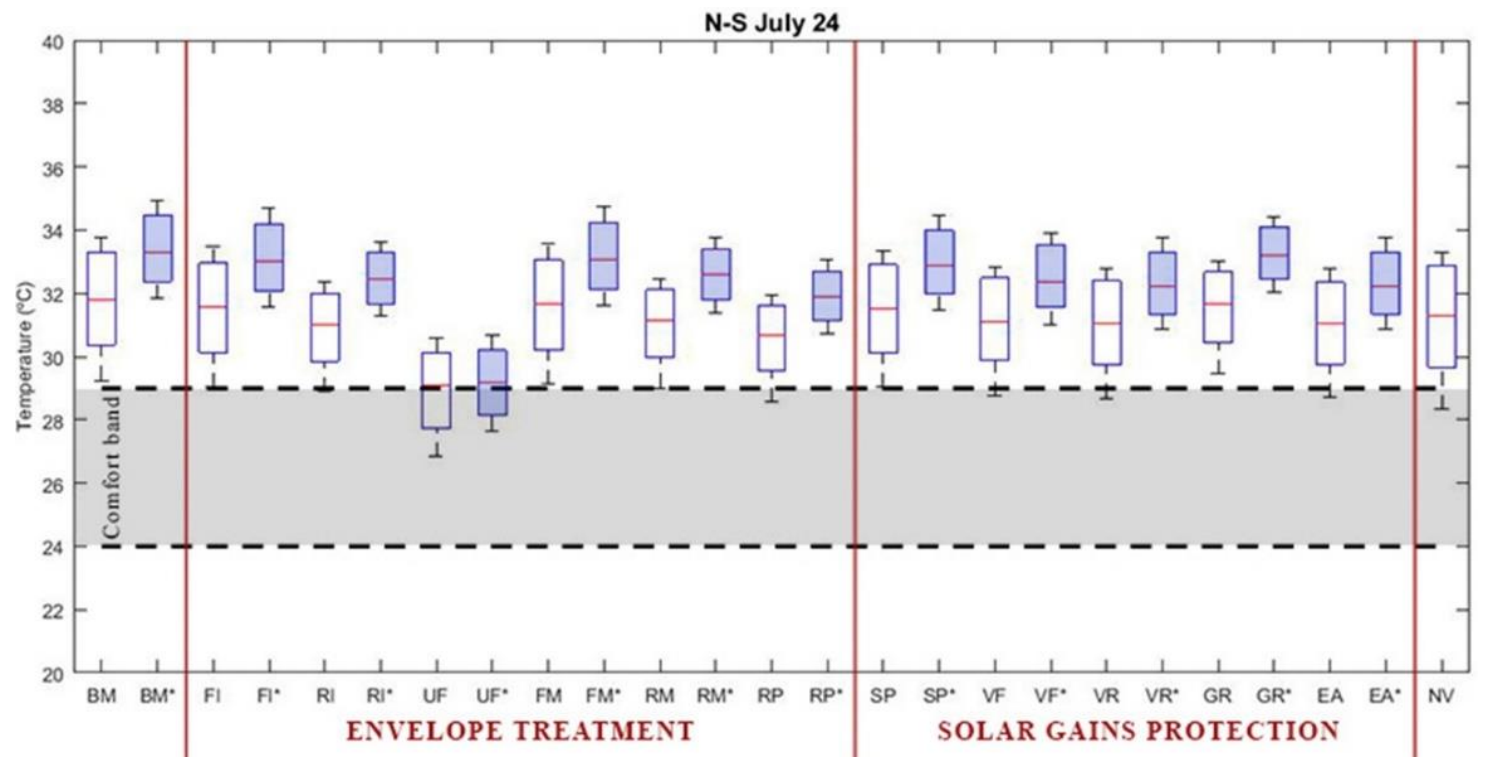

Figure 8. Daily fluctuation of the indoor operative temperature in the 2050 climate scenario with passive conditioning solutions. Summer, North-South orientation. NOTE: XX* (filled boxplot) is the XX passive conditioning solution but without night-time natural ventilation. LEGEND: Base Model (BM); Façade Insulation (FI); Roof Insulation (RI); Uninsulated Floor (UF); Façade thermal Mass (FM); Roof thermal Mass (RM); Roof Pond (RP); Solar Protection (SP); Ventilated Façades (VF); Ventilated Roofs (VR); Green Roofs (GR); Envelope absorptivity (EA); Natural Ventilation (NV).

The increase in façade insulation (FI) or the use of the green roof (GR) barely impact indoor operative temperatures. The solar protections (SP), the façades and roof absorptivity reduction (EA), the increase in the roof insulation (RI), and the increase in the roof slab thermal mass (RM) or the ventilated roof (VR) are solutions which provide positive but less significant effects, causing variations in the average operative temperature in the range of $0.7-1{ }^{\circ} \mathrm{C}$. Although none of the passive conditioning strategies evaluated individually reduce the indoor operative temperatures sufficiently to guarantee comfortable thermal conditions in a free-running scenario, the improvement they represent is enough to predict that by carefully combining some solutions the average indoor operative temperature could be maintained within the comfort temperature band.

It should be noted that all proposed solutions are simulated during the summer period with and without night-time natural ventilation in order to quantify the influence of this passive conditioning solution in the severe summer scenario for 2050. The standard user profile establishes a night-time ventilation rate of $4 \mathrm{ACH}$ for summer, which responds to the most usual habit although not all users have it. When users do not ensure ventilation at night-time, the indoor temperature in all the solutions evaluated increases by up to $2.5{ }^{\circ} \mathrm{C}$ during the day and $3.5{ }^{\circ} \mathrm{C}$ during the night.

In order to complete the environmental analysis, the effect of the passive conditioning solutions proposed (with night-time natural ventilation) on comfort is evaluated throughout the summer period (June-September). Tables 4 and 5 show the maximum and minimum indoor operative temperatures, the percentage of hours outside the comfort temperature band and the average deviation of the indoor operative temperatures (in the periods of discomfort) with respect to the upper limit of the comfort band. As can be observed, the effect of passive conditioning solutions is not exactly the same when evaluating temperature and percentage of hours of discomfort (Figure 9). The solution with the greatest improvement in comfort conditions in summer is that of the non-insulation of the ground floor (UF), which causes a reduction of around $40 \%$ in the hours of discomfort in the model with the East-West orientation (which goes from $75 \%$ in the base model (BM) to $35 \%$ in the UF model) and a reduction of $1.9^{\circ} \mathrm{C}$ in the average deviation of the indoor temperatures with respect to the upper limit of the comfort band (from $3{ }^{\circ} \mathrm{C}$ in the BM to $1.1^{\circ} \mathrm{C}$ in the UF model). The following most effective measures 
in terms of comfort are the ventilated façade (VF), the increase in night-time natural ventilation rate $(\mathrm{NV})$ and the envelope absorptivity reduction (EA), which result in decreases in the percentage of discomfort hours in the range of $8-17 \%$.

Measures such as the Green roof (GR) or the increase of the façade (FM) and roof thermal mass (RM), which barely cause a change in the average indoor temperature, result in an increase of around $1-5 \%$ of discomfort hours. The increase of the roof insulation (RI) results in different behaviour depending on the orientation: in the East-West-oriented model, it represents an increase of $0.8 \%$ in the percentage of discomfort hours; while in the North-South one it produces a decrease of $6.7 \%$. This is due to the fact that indoor temperature and, therefore, overheating is greater in the East-West orientation, thus creating a greater need to dissipate the heat, an action which is further complicated by this solution.

Table 4. Characterization of environmental behaviour (indoor operative temperature and comfort level) in the 2050 climate scenario with passive conditioning solutions. Summer, East-West orientation.

\begin{tabular}{|c|c|c|c|c|c|}
\hline \multirow{2}{*}{\multicolumn{2}{|c|}{ Type of Strategy }} & \multicolumn{4}{|c|}{ East-West Summer Period (June-September) } \\
\hline & & \multirow{2}{*}{$\begin{array}{c}\text { Maximum } \\
\text { Temperature }\left({ }^{\circ} \mathrm{C}\right)\end{array}$} & \multirow{2}{*}{$\begin{array}{c}\text { Minimum } \\
\text { Temperature }\left({ }^{\circ} \mathrm{C}\right)\end{array}$} & \multirow{2}{*}{$\begin{array}{c}\begin{array}{c}\text { Discomfort } \\
\text { Hours (\%) }\end{array} \\
75.4\end{array}$} & \multirow{2}{*}{$\begin{array}{c}\begin{array}{c}\text { Average } \\
\text { Deviation }\left({ }^{\circ} \mathrm{C}\right)\end{array} \\
2.98\end{array}$} \\
\hline & e model & & & & \\
\hline \multirow{6}{*}{$\begin{array}{l}\text { Envelope } \\
\text { treatment }\end{array}$} & Façade Insulation & 37.4 & 23.5 & 75.1 & 2.94 \\
\hline & Roof Insulation & 36.2 & 24.4 & 76.2 & 2.62 \\
\hline & Uninsulated Floor & 32.5 & 21.5 & 35.1 & 1.11 \\
\hline & Façade thermal Mass & 37.6 & 23.7 & 76.7 & 3.03 \\
\hline & Roof thermal Mass & 36.2 & 24.6 & 78.3 & 2.67 \\
\hline & Roof Pond & 35.8 & 24.3 & 72.7 & 2.40 \\
\hline \multirow{5}{*}{$\begin{array}{l}\text { Solar gain } \\
\text { protection }\end{array}$} & Solar Protection & 36.9 & 23.0 & 70.4 & 2.60 \\
\hline & Ventilated Façades & 35.8 & 22.8 & 60.6 & 2.14 \\
\hline & Ventilated Roofs & 36.7 & 23.2 & 70.3 & 2.57 \\
\hline & Green Roofs & 36.9 & 24.7 & 81.3 & 2.90 \\
\hline & Envelope absorptivity & 36.4 & 23.1 & 67.9 & 2.45 \\
\hline \multicolumn{2}{|c|}{ Natural ventilation } & 36.9 & 22.0 & 62.4 & 2.55 \\
\hline
\end{tabular}

Table 5. Characterization of environmental behaviour (indoor operative temperature and comfort level) in the 2050 climate scenario with passive conditioning solutions. Summer, North-South orientation.

\begin{tabular}{|c|c|c|c|c|c|}
\hline \multirow{2}{*}{\multicolumn{2}{|c|}{ Type of Strategy }} & \multicolumn{4}{|c|}{ East-West Summer Period (June-September) } \\
\hline & & $\begin{array}{c}\text { Maximum } \\
\text { Temperature }\left({ }^{\circ} \mathrm{C}\right)\end{array}$ & $\begin{array}{c}\text { Minimum } \\
\text { Temperature }\left({ }^{\circ} \mathrm{C}\right)\end{array}$ & $\begin{array}{l}\text { Discomfort } \\
\text { Hours }(\%)\end{array}$ & $\begin{array}{c}\text { Average } \\
\text { Deviation }\left({ }^{\circ} \mathrm{C}\right)\end{array}$ \\
\hline \multicolumn{2}{|c|}{ Base model } & 34.0 & 22.8 & 53.3 & 1.61 \\
\hline \multirow{6}{*}{$\begin{array}{l}\text { Envelope } \\
\text { treatment }\end{array}$} & Façade Insulation & 33.8 & 22.9 & 52.5 & 1.55 \\
\hline & Roof Insulation & 32.7 & 23.3 & 46.6 & 1.25 \\
\hline & Uninsulated Floor & 30.6 & 20.9 & 18.2 & 0.48 \\
\hline & Façade thermal Mass & 33.9 & 23.0 & 54.3 & 1.62 \\
\hline & Roof thermal Mass & 32.9 & 23.7 & 52.5 & 1.33 \\
\hline & Roof Pond & 32.3 & 23.2 & 39.3 & 1.20 \\
\hline \multirow{5}{*}{$\begin{array}{l}\text { Solar gain } \\
\text { protection }\end{array}$} & Solar Protection & 33.5 & 22.6 & 47.6 & 1.45 \\
\hline & Ventilated Façades & 33.1 & 22.3 & 36.4 & 1.30 \\
\hline & Ventilated Roofs & 33.0 & 22.3 & 41.6 & 1.29 \\
\hline & Green Roofs & 33.4 & 23.8 & 57.8 & 1.54 \\
\hline & Envelope absorptivity & 33.0 & 22.4 & 41.6 & 1.29 \\
\hline \multicolumn{2}{|c|}{ Natural ventilation } & 33.5 & 21.4 & 40.7 & 1.44 \\
\hline
\end{tabular}




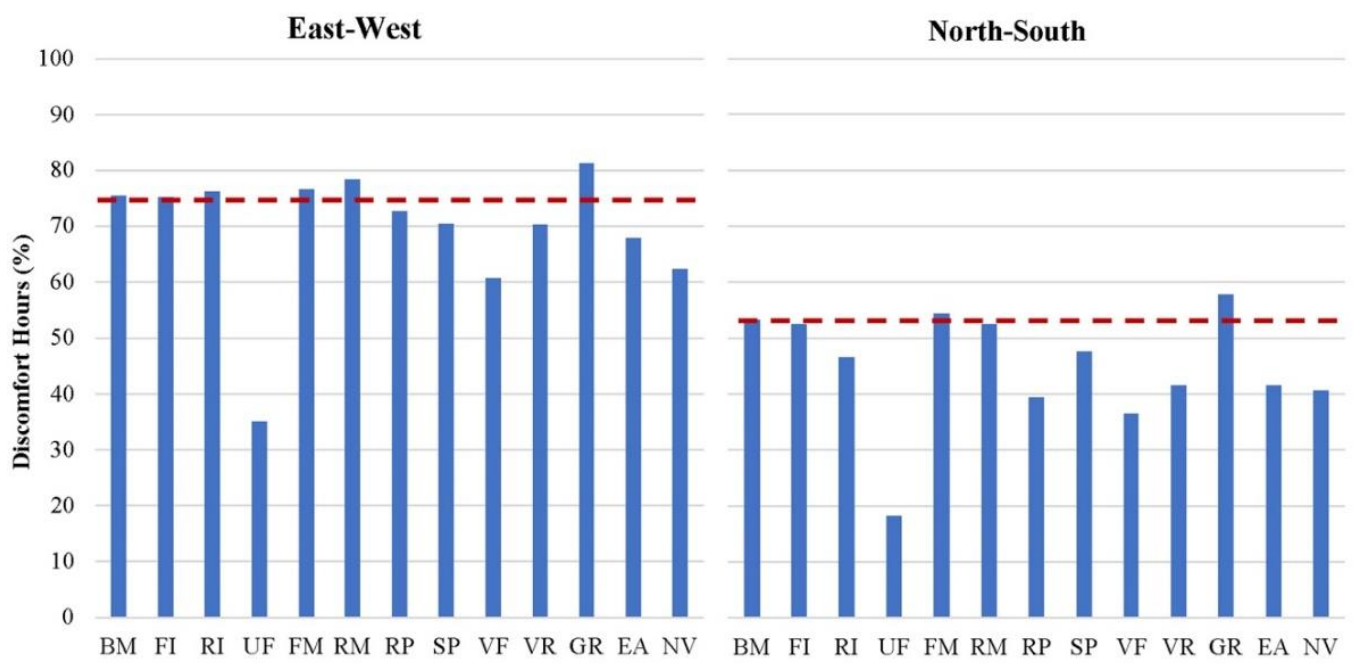

Figure 9. Percentage of discomfort hours in the 2050 climate scenario with passive conditioning solutions. Summer (June-September).

\section{Conclusions}

Different passive conditioning strategies are proposed for application to a single-family reference building in southern Spain as a way to tackle the new challenges posed by the 2050 climate change scenarios. Energy performance has been evaluated by first simulating the energy demand in current climatic conditions and subsequently in an A2 scenario of climate change in the year 2050.

The increase in outdoor temperatures in a climate scenario of 2050 , of about $1.5{ }^{\circ} \mathrm{C}$ in winter and $6{ }^{\circ} \mathrm{C}$ in summer, will result in a significant energy impact in the single-family home in southern Spain. Demand will be reduced in winter but will double in summer compared to the current Spanish regulation requirements. This implies an increase of indoor operative temperatures in summer of about $3.5^{\circ} \mathrm{C}$ compared to the current ones, with maximum daytime values of $37.5^{\circ} \mathrm{C}$ and $31{ }^{\circ} \mathrm{C}$ of minimum value in the night period, values far from thermal comfort conditions.

Given the overheating problems in summer, adequate passive strategies could be considered to favour controlled exchanges between indoors and outdoors, as an alternative way of dealing with the energy management of the home. Strategies for the improvement of thermal insulation through the increase in thermal resistance are not effective in resolving issues in overheating, and even cause a slight increase in the percentage of discomfort hours. Heat dissipation must be ensured, either continuously by reducing the thermal resistance of the ground floor, or at night through natural ventilation, which can lead to a significant drop in average and nightly indoor operative temperatures by up to $3.5-4.5^{\circ} \mathrm{C}$, and in the percentage of discomfort hours by $14-40 \%$.

The use of adequate passive conditioning techniques allows thermal oscillations to be reduced, increasing comfort, mainly in the summer period. Among the solutions evaluated, the most efficient are those related to protection against solar radiation: the façade solar protection with ventilated façade systems; the roof solar protection with roof pond or ventilated roof solutions; and the reduction of the solar absorptance of the envelope and windows with suitable shading devices. These solutions, together with a night-time natural ventilation rate of $8 \mathrm{ACH}$, achieve a maximum decrease in the average indoor temperature of $1-2.5^{\circ} \mathrm{C}$, reducing the maximum and minimum indoor temperature by $1-2{ }^{\circ} \mathrm{C}$, and the percentage of discomfort hours by $8-17 \%$.

This study is proposed as a first-stage assessment tool for checking the feasibility of different passive conditioning solutions, to be completed with an analysis of combined solutions and an adequate optimization of the whole. Future studies should evaluate the embodied energy increasement that entails the proposed changes on the envelope. Although the use of passive measures supposes 
significant improvements in the buildings energy performance, it will be necessary to incorporate renewable energies to achieve the 2050 requirements.

Author Contributions: Conceptualization, R.S., R.E. and R.L.-P.; Investigation, R.S., R.E. and R.L.-P.; Methodology, R.S., R.E. and R.L.-P.; Project administration, R.S.; Writing—Original draft, all authors.

Funding: This research was funded by the Spanish government through the research and development projects "Energy Rehabilitation of tertiary buildings in Mediterranean climate by optimizing Solar Protection Systems" (ref BIA2014-53949-R) and "Parametric optimization of double-skin façades in the Mediterranean climate to improve energy efficiency under climate change scenarios" (ref BIA2017-86383-R).

Conflicts of Interest: The authors declare no conflict of interest. The funders had no role in the design of the study; in the collection, analyses, or interpretation of data; in the writing of the manuscript, and in the decision to publish the results.

\section{References}

1. IPCC. History of the IPCC. Available online: http://www.ipcc.ch/organization/organization_history.shtml (accessed on 15 August 2018).

2. IPCC. Fifth Assessment Report on Climate Change. 2014. Available online: http://www.ipcc.ch/report/ ar5/index.shtml (accessed on 15 February 2018).

3. IPCC. Special Report on Emissions Scenarios (SRES). Nebojsa Nakicenovic and Rob Swart, Ed.; Cambridge University Press: UK, 2000. Available online: http://www.ipcc.ch/ipccreports/sres/emission/index.php? idp $=0$ (accessed on 15 February 2018).

4. Directive 2012/27/EU of the European Parliament and of the Council. Available online: http:/ / eur-lex. europa.eu/legal-content/EN/TXT/PDF/?uri=CELEX:32012L0027\&from=EN (accessed on 15 May 2018).

5. Communication from the Commission to the European Parliament, the Council, the European Economic and Social Committee and the Committee of the Regions. A Policy Framework for Climate and Energy in the Period from 2020 to 2030. Available online: http:/ / eur-lex.europa.eu/legal-content/EN/TXT/?uri= COM\%3A2014\%3A15\%3AFIN (accessed on 15 May 2018).

6. Eurostat. Final Energy Consumption by Sector. 2015. Available online: http://ec.europa.eu/eurostat/ statistics-explained/index.php/Consumption_of_energy\#Consumption (accessed on 15 August 2018).

7. Fuller, R.J.; Crawford, R.H. Impact of past and future residential housing development patterns on energy demand and related emissions. J. Hous. Built Environ. 2011, 26, 65-183. [CrossRef]

8. Du, P.; Wood, A.; Stephens, B. Empirical Operational Energy Analysis of Downtown High-Rise vs. Suburban Low-Rise Lifestyles: A Chicago Case Study. Energies 2016, 9, 445. [CrossRef]

9. Eurostat. Housing Statistics. Available online: http://ec.europa.eu/eurostat/statistics-explained/index. php?title=Housing_statistics\#Type_of_dwelling (accessed on 7 August 2018).

10. Santamouris, M.; Kolokotsa, D. On the impact of urban overheating and extreme climatic conditions on housing, energy, comfort and environmental quality of vulnerable population in Europe. Energy Build. 2015, 98, 125-133. [CrossRef]

11. Coley, D.; Kershaw, T. Changes in internal temperatures within the built environment as a response to a changing climate. Build. Environ. 2010, 45, 89-93. [CrossRef]

12. Indoor Air Pollution: New EU Research Reveals Higher Risks than Previously thought European Commission—IP/03/1278; EU Commission: Brussels, Belgium, 2003.

13. Tzikopoulos, A.F.; Karatza, M.C.; Paravantis, J.A. Modeling energy efficiency of bioclimatic buildings. Energy Build. 2005, 37, 529-544. [CrossRef]

14. Yau, Y.H.; Pean, H.L. The performance study of a split type air conditioning system in the tropics, as affected by weather. Energy Build. 2014, 72, 1-7. [CrossRef]

15. The European Platform against Poverty and Social Exclusion: A European Framework for Social and Territorial cohesion. In Communication from the Commission to the European Parliament, the Council, the European Economic and Social Committee and the Committee of the Regions; European Commission: Brussels, Belgium, 2010.

16. Ascione, F. Energy conservation and renewable technologies for buildings to face the impact of the climate change and minimize the use of cooling. Sol. Energy 2017, 154, 34-100. [CrossRef] 
17. Pacheco, R.; Ordóñez, J.; Martínez, G. Energy efficient design of building: A review. Renew. Sustain. Energy Rev. 2012, 16, 3559-3573. [CrossRef]

18. Idris, Y.; Mae, M. Anti-insulation Mitigation by Altering the Envelope Layers' Configuration. Energy Build. 2017, 141, 186-204. [CrossRef]

19. León, A.L.; Suárez, R.; Bustamante, P.; Campano, M.A.; Moreno, D. Design and Performance of Test Cells as an Energy Evaluation Model of Facades in a Mediterranean Building Area. Energies 2017, 10, 1816. [CrossRef]

20. Jaber, S.; Ajib, S. Optimum technical and energy efficiency design of residential building in Mediterranean region. Energy Build. 2011, 43, 1829-1834. [CrossRef]

21. Al-Sanea, S.A.; Zedan, M.F. Effect of thermal bridges on transmission loads and thermal resistance of building walls under dynamic conditions. Appl. Energy 2012, 98, 584-593. [CrossRef]

22. Wang, L.-S.; Ma, P.; Hu, E.; Giza-Sisson, D.; Mueller, G.; Guo, N. A study of building envelope and thermal mass requirements for achieving thermal autonomy in an office building. Energy Build. 2014, 78, 79-88. [CrossRef]

23. Orosa, J.A.; Oliveira, A.C. A field study on building inertia and its effects on indoor thermal environment. Renew. Energ 2012, 37, 89-96. [CrossRef]

24. Aste, N.; Angelotti, A.; Buzzetti, M. The influence of the external walls thermal inertia on the energy performance of well insulated buildings. Energy Build. 2009, 41, 1181-1187. [CrossRef]

25. Sharifi, A.; Yamagata, Y. Roof ponds as passive heating and cooling systems: A systematic review. Appl. Energy 2015, 160, 336-357. [CrossRef]

26. Spanaki, A.; Kolokotsa, D.; Tsoutsos, T.; Zacharopoulos, I. Assessing the passive cooling effect of the ventilated pond protected with a reflecting layer. Appl. Energy 2014, 123, 273-280. [CrossRef]

27. Yadav, R.; Rao, D.P. Digital simulation of indoor temperatures of buildings with roof ponds. Sol. Energy 1983, 31, 205-215. [CrossRef]

28. Spanaki, A.; Tsoutsos, T.; Kolokotsa, D. On the selection and design of the proper roof pond variant for passive cooling purposes. Renew. Sustain. Energy Rev. 2011, 15, 3523-3533. [CrossRef]

29. Coma, J.; Pérez, G.; Solé, C.; Castell, A.; Cabeza, L.F. Thermal assessment of extensive green roofs as passive tool for energy savings in buildings. Renew. Energy 2016, 85, 1106-1115. [CrossRef]

30. Niachou, A.; Papakonstantinou, K.; Santamouris, M.; Tsangrassoulis, A.; Mihalakakou, G. Analysis of the green roof thermal properties and investigation of its energy performance. Energy Build. 2001, 33, 719-729. [CrossRef]

31. Goudarzi, H.; Mostafaeipour, A. Energy saving evaluation of passive systems for residential buildings in hot and dry regions. Renew. Sustain. Energy Rev. 2017, 68, 432-446. [CrossRef]

32. Saadatian, O.; Sopian, K.; Salleh, E.; Lim, C.H.; Riffat, S.; Saadatian, E.; Toudeshki, A.; Sulaiman, M.Y. A review of energy aspects of green roofs. Renew. Sustain. Energy Rev. 2013, 23, 155-168. [CrossRef]

33. Ascione, F.; Bianco, N.; de' Rossi, F.; Turni, G.; Vanoli, G.P. Green roofs in European climates. Are effective solutions for the energy savings in air-conditioning? Appl. Energy 2013, 104, 845-859. [CrossRef]

34. Zinzi, M.; Agnoli, S. Cool and green roofs. An energy and comfort comparison between passive cooling and mitigation urban heat island techniques for residential buildings in the Mediterranean region. Energy Build. 2012, 55, 66-76. [CrossRef]

35. Kolokotsa, D.; Diakaki, C.; Papantoniou, S.; Vlissidis, A. Numerical and experimental analysis of cool roofs application on a laboratory building in Iraklion, Crete, Greece. Energy Build. 2011, 55, 85-93. [CrossRef]

36. Synnefa, A.; Santamouris, M.; Livada, I. A study of the thermal performance of reflective coatings for the urban environment. Sol. Energy 2006, 80, 968-981. [CrossRef]

37. Stevanović, S. Optimization of passive solar design strategies: A review. Renew. Sustain. Energy Rev. 2013, 25, 177-196. [CrossRef]

38. León, A.L.; Domínguez, S.; Campano, M.A.; Ramírez-Balas, C. Reducing the Energy Demand of Multi-Dwelling Units in a Mediterranean Climate Using Solar Protection Elements. Energies 2012, 5, 3398-3424. [CrossRef]

39. Seok, H.; Jo, J.; Kim, K. Establishing the design process of double-skin facade elements through design parameter analysis. J. Asian Archit. Build. Eng. 2009, 8, 251-258. [CrossRef]

40. Ciampi, M.; Leccese, F.; Tuoni, G. Ventilated facades energy performance in summer cooling of buildings. Sol. Energy 2003, 75, 491-502. [CrossRef] 
41. Suárez, M.J.; Sanjuan, C.; Gutiérrez, A.J.; Pistono, J.; Blanco, E. Energy evaluation of an horizontal open joint ventilated façade. Appl. Therm. Eng. 2012, 37, 302-313. [CrossRef]

42. Sanjuan, C.; Suárez, M.J.; González, M.; Pistono, J.; Blanco, E. Energy performance of an open-joint ventilated façade compared with a conventional sealed cavity façade. Sol. Energy 2011, 85, 1851-1863. [CrossRef]

43. Peci López, F.; Jensen, R.L.; Heiselberg, P.; Ruiz de Adana Santiago, M. Experimental analysis and model validation of an opaque ventilated façade. Build. Environ. 2012, 56, 265-275. [CrossRef]

44. Solgi, E.; Fayaz, R.; Kari, B.M. Cooling load reduction in office buildings of hot-arid climate, combining phase change materials and night purge ventilation. Renew. Energy 2016, 85, 725-731. [CrossRef]

45. Santamouris, M.; Kolokotsa, D. Passive cooling dissipation techniques for buildings and other structures: The state of the art. Energy Build. 2013, 57, 74-94. [CrossRef]

46. Campaniço, H.; Hollmuller, P.; Soares, P.M.M. Assessing energy savings in cooling demand of buildings using passive cooling systems based on ventilation. Appl. Energy 2014, 134, 426-438. [CrossRef]

47. Lazzarin, R.M.; Noro, M. Energetic and economic savings of free cooling in different European climates. Int. J. Low-Carbon Technol. 2009, 4, 213-223. [CrossRef]

48. Ministerio de Vivienda. Código Técnico de la Edificación (CTE) Documento Básico de Ahorro de Energía (DB-HE). 2017. Available online: https://www.codigotecnico.org/images/stories/pdf/ahorroEnergia/ DcmHE.pdf (accessed on 15 May 2018).

49. DesignBuilder. Available online: https://www.designbuilder.co.uk (accessed on 18 May 2018).

50. University of Southampton. Climate Change World Weather File Generator for World-Wide Weather Data -CCWorldWeatherGen. Available online: http://www.energy.soton.ac.uk/ccworldweathergen/ (accessed on 15 November 2017).

51. Jentsch, M.F.; James, P.A.B.; Bourikas, L.; Bahajb, A.S. Transforming existing weather data for worldwide locations to enable energy and building performance simulation under future climates. Renew. Energy 2011, 55, 514-524. [CrossRef]

52. Reichler, T.; Kim, J. How Well Do Coupled Models Simulate Today's Climate? Bull. Am. Meteorol. Soc. 2008, 89, 303-311. [CrossRef]

53. Barbadilla-Martín, E.; Salmerón, J.M.; Guadix, J.; Aparicio-Ruiz, P.; Brotas, L. Field study on adaptive thermal comfort in mixed mode office buildings in southwestern area of Spain. Build. Environ. 2017, 123, 163-175. [CrossRef]

54. Eumorfopoulou, E.; Aravantinos, D. The contribution of a planted roof to the thermal protection of buildings in Greece. Energy Build. 1998, 27, 29-36. [CrossRef]

55. Peel, M.C.; Finlayson, B.L.; McMahon, T.A. Updated world map of the Köppen-Geiger climate classification. Hydrol. Earth Syst. Sci. 2007, 11, 1633-1644. [CrossRef]

56. Weather Data Download-Cordoba 084100 (SWEC). Available online: https://energyplus.net/weatherlocation/europe_wmo_region_6/ESP / /ESP_Cordoba.084100_SWEC (accessed on 15 November 2017).

57. Instituto Eduardo Torroja de Ciencias de la Construcción. Catálogo de elementos Constructivos del CTE. 2010. Available online: https:/ / www.codigotecnico.org/images/stories/pdf/aplicaciones/nCatalog infoEConstr/CAT-EC-06.3_marzo_10.pdf (accessed on 5 Jun 2018).

58. Ministerio de Vivienda. Código Técnico de la Edificación (CTE) Documento Básico de Salubridad (DB-S). 2017. Available online: https://www.codigotecnico.org/images/stories/pdf/salubridad/DcmHS.pdf (accessed on 15 May 2018).

(C) 2018 by the authors. Licensee MDPI, Basel, Switzerland. This article is an open access article distributed under the terms and conditions of the Creative Commons Attribution (CC BY) license (http://creativecommons.org/licenses/by/4.0/). 